\title{
A análise da narrativa dos pacientes com HIV na construção da adesão terapêutica
}

| ${ }^{1}$ Debora Carvalho Ferreira, ${ }^{2}$ Cesar Augusto Orazem Favoreto I

Resumo: A adesão terapêutica para portadores da Síndrome da Imunodeficiência Adquirida (SIDA/ Aids) necessita ser abordada em uma perspectiva multifatorial e singular, que considere aspectos socioculturais, significados construídos e autonomia dos indivíduos. Este estudo qualitativo visa explorar os elementos e formas narrativas desenvolvidas pelos pacientes para promoverem a adesão. Foram realizadas entrevistas em profundidade com nove pacientes com SIDA que apresentavam boa adesão e resposta clínico-laboratorial ao tratamento. A análise das falas identificou os contextos e os recursos narrativos que impulsionaram essas pessoas a enfrentarem a doença e suas repercussões que influenciaram na adesão.

Observou-se que o tempo nas narrativas sobre a adesão não era cronológico e as justificativas/explicações para lidar com o contágio, a doença e os preconceitos envolvidos, assumiam uma dimensão terapêutica. $\mathrm{O}$ papel de protagonista em relação às estórias de vida e o adoecimento emergiu como elemento central no enfrentamento das rupturas advindas do adoecimento, e influenciou na incorporação da adesão em uma perspectiva terapêutica.

> Palavras-chave: Síndrome de Imunodeficiência Adquirida; cooperação do paciente; medicina narrativa, doenças crônicas.
1 Médica especialista em Medicina de Família e Comunidade. Mestranda em saúde coletiva pela Faculdade de Medicina da Universidade Federal de Juiz de Fora (UFJF). Endereço eletrônico: deborajf@ yahoo.com.br

\footnotetext{
2 Médico. Doutor em saúde coletiva pelo IMS/ UERJ. Professor adjunto do departamento de medicina integral e familiar e comunitário FCM/UERJ; pesquisador colaborador do LAPPIS. Endereço eletrônico cesarfavoreto@globo.com
}

Recebido em: 28/06/2010 Aprovado em: 29/07/2011 


\section{Introdução}

O desenvolvimento da epidemia de Aids no Brasil tem apresentado mudanças relevantes na última década. A redução da mortalidade, devido aos efeitos positivos da terapia antirretroviral, transformou a infecção em uma doença crônica (SCHAURICH; COELHO; MOTTA, 2006). Em outro sentido, a expansão da infecção tem sido maior sobre grupos populacionais que apresentam uma maior vulnerabilidade social e cultural.

No Brasil, a garantia de acesso ao tratamento medicamentoso continuado pelo Programa de DST/Aids tem sido exitosa, porém implica um constante desafio em relação à adesão e à garantia de uma qualidade de vida satisfatória, apesar dos estigmas ainda fortes em nossa sociedade. Para enfrentar esse desafio é importante que a visão da adesão vá além da tomada regular de medicamentos, e abarque também o modo de vida do sujeito, que seria capaz de levar a uma autonomia no curso do adoecimento (BRASIL/MS 2005).

Reiners et al. (2008), a partir de revisão da literatura latino-americana, identificou a necessidade de investimento contínuo em pesquisas que abordem o fenômeno da adesão/não-adesão no curso de doenças crônicas. Esses autores identificaram que os trabalhos se estabelecem entorno da ideia de que o paciente deve cumprir, seguir e obedecer às recomendaçōes dos profissionais de saúde, e que seu comportamento deve coincidir com os conselhos e indicaçôes médicas. Assim, a maior carga de responsabilidade pela adesão/não-adesão ao tratamento é conferida ao paciente, reduzindo a responsabilidade dos profissionais e serviços de saúde nesse processo.

A culpabilização dos pacientes e o baixo envolvimento dos profissionais nesse processo estão inseridos em uma visão da terapêutica que segue um modo de ver e agir normativo, centrado apenas nos parâmetros biomédicos, sem valorizar a escuta da vivência do paciente nesse processo, afastando a experiência do cotidiano do ato terapêutico em si.

A questão que se coloca em destaque é a diferença entre o que o profissional considera como adesão e o que o individuo, sujeito dessa adesão, compreende. No escopo da visão profissional, Leite (2003) coloca que, apesar do conceito de adesão ser variável na literatura, de forma geral, um paciente pode ser considerado bem aderido quando utiliza medicamentos e outras prescrições em uma frequência de, pelo menos, $80 \%$ do esperado. 
$\mathrm{Na}$ abordagem da adesão na perspectiva do individuo, Brawley e Reed (2000)

ressaltam a importância da motivação nesse processo, a qual dependeria de uma coparticipação ativa dos pacientes dentro de uma negociação terapêutica particular. Nesse processo estariam envolvidos: questôes relativas ao paciente (crenças, expectativas); a doença (severidade, complicações); o tratamento da doença (duração, efeitos colaterais); e a relação com o serviço de saúde e com os profissionais que estão envolvidos no projeto terapêutico (MEICHENBAUM; TURK, apud BRAWLEY; REED, 2000).

A incorporação da perspectiva dos pacientes na prevenção e na avaliação da adesão implica ampliar os horizontes de sua abordagem pelos profissionais de saúde, o que se traduz numa visão e numa ação que transcende os aspectos puramente quantitativos dos parâmetros biomédicos (número de comprimidos tomados, comparecimento às consultas, resultados de exames laboratoriais, etc.) e compreende, por sua vez, a valorização das distintas dimensões do sujeito sobre a terapêutica. Dessa forma, a abordagem da terapêutica, e, consequentemente, da adesão, é assumida nesse trabalho como um processo dinâmico, multifatorial, baseado em decisões compartilhadas e corresponsabilidades entre usuários, equipe de saúde e rede social, visando atender aspectos sócio-culturais e subjetivos dos pacientes (FRANK, 1995; BRASIL, 2005).

Para desenvolver esse fazer terapêutico na clínica, o primeiro passo é reconhecer as limitações produzidas pela racionalidade biomédica e pelo estilo de pensamento mecanicista e fragmentado dela decorrente (CAMARGO JR, 2003). Isso significa compreender que os conhecimentos sobre a doença são insuficientes para o sucesso prático no que se refere ao alargamento dos modos das pessoas andarem a vida (MATTOS, 2008).

A terapêutica, a partir do conceito de normalidade desenvolvido por Canguilhem (1982), é entendida como um movimento dirigido à autonomia frente às limitaçôes produzidas pelo adoecimento. Nesse sentido, Mattos (2008) indica que o sucesso prático das intervenções em saúde se realiza, justamente, a partir da construção de uma relação emancipatória entre o profissional e o usuário.

Delineia-se uma visão da terapêutica que está fundada em uma autonomia construída na articulação do conhecimento biomédico com outros saberes não biomédicos e em uma relação dialógica e emancipatória entre o cuidador e quem busca o cuidado. Uma perspectiva terapêutica que tem como referência os modos 
concretos de andar a vida frente ao adoecimento vivido e às concepções, temores e sentimentos das pessoas que o sofrem (MATTOS, 2008).

Considerar as perspectivas pessoais do e sobre o adoecimento como elemento central da abordagem terapêutica requer integrar o paciente tanto como sujeito no processo de enfrentamento das rupturas causadas pela situação de adoecimento, quanto como mediador entre as intervenções médicas e como promotor de normatizar novas normas de vida (CANGUILHEM, 1982; BONET; TAVARES, 2008).

Para enfrentar as limitações e repercussões provocadas pelo adoecimento e tratamento, as pessoas constroem estórias que têm características diversas de acordo com a forma como dispõem os elementos envolvidos em suas vidas. Através dessas estórias são encontradas formas capazes de expressar as desordens e os medos delas decorrentes e de possibilitar que elas deem forma e promovam o controle sobre o caos e as rupturas provocadas pela enfermidade (DONALD, 2002; CHARON, 2004; FRANK, 1995). Esse é um modo de pensar e agir no cenário clínico-terapêutico que se dirige para além das alterações fisiopatológicas, pois dá destaque à produção de narrativas a partir do encontro entre profissionais e pacientes (FAVORETO, 2007). Por sua vez, o movimento de revalorizar e ressignificar a estória narrada permite conduzir as intervenções com base nas perspectivas e valores reais e singulares dos pacientes (FAVORETO, 2006).

Essas estórias e suas formas constituem narrativas que Brockmeier \& Harré (2003) veem como um conjunto de estruturas linguísticas e psicológicas transmitidas cultural e historicamente, delimitadas pelo nível do domínio de cada individuo e pela combinação de técnicas sócio-comunicativas e habilidades linguísticas individuais.

Através das estórias narradas, é possível reconhecer como os determinantes biopsicossociais são agenciados pelos pacientes para fazer parte do seu mundo e desenvolver um modo de conduzir a vida em um meio ambiente particular (BONET; TAVARES, 2008). Compreende-se, através das falas e atitudes, como as pessoas enfrentam as vulnerabilidades e rupturas anteriores ou decorrentes de um processo de adoecimento como a infecção pelo HIV, e como esse agenciamento pode influir na adesão terapêutica.

Foi em torno da relevância de tais contextos e das construções narrativas pessoais dirigidas a alcançar um sucesso prático frente ao adoecimento por SIDA 
que este trabalho se estruturou. Nesse sentido, optou-se por explorar os elementos

envolvidos com o sucesso terapêutico e não com os motivos da não adesão, como tem sido mais enfatizado na literatura sobre o tema, e é a partir dessas questôes que este trabalho busca contribuir para ampliar a abordagem sobre a adesão. Para isso investigou-se quais e como são operados os recursos narrativos e práticos desenvolvidos pelos pacientes para alcançar bons resultados terapêuticos, que não se limitam aos parâmetros biomédicos, mas envolvem a participação do sujeito na terapêutica, sua motivação e seu olhar sobre seu próprio tratamento. (BRAWLEY; REED, 2000).

O objetivo da pesquisa foi o de explorar e analisar os recursos narrativos e práticos desenvolvidos por portadores de SIDA/Aids acompanhados em um ambulatório universitário, para alcançar os bons resultados terapêuticos que contemplam uma adesão ampliada ao tratamento e ao enfrentamento das vulnerabilidades vividas.

\section{Método}

O propósito desta pesquisa surgiu através de questionamentos emergidos na prática de um ambulatório de saúde do adulto realizado no contexto da Residência de Medicina de Família e Comunidade, e não estava ligado a nenhum projeto de pesquisa anteriormente existente. As entrevistas aconteceram nos meses de maio a junho de 2008. Os pesquisadores atuavam, na época da pesquisa, como residente e preceptor da residência, respectivamente. Contudo, foram evitadas entrevistas com os próprios pacientes aos quais eles mantinham vínculo, para evitar vieses de resposta. A pesquisa foi aprovada pelo Comitê de Ética do HUPE/UERJ e as entrevistas foram gravadas com autorização dos pacientes, a participação foi voluntária, e foi assegurado o caráter confidencial de suas falas. Depois de explicados os objetivos da pesquisa, era feita a leitura do Termo de Consentimento livre e esclarecido com a assinatura dos mesmos (Resolução 196/96 Brasil 1996). Para garantir o anonimato foram utilizados nomes fictícios.

Foram realizadas entrevistas em profundidade, nas quais foi possível escutar, analisar e interpretar as narrativas de pessoas portadoras de SIDA/Aids. Para o estudo foram entrevistados nove pacientes que, apesar de expostos a condições de vulnerabilidade físicas, psicológicas, sociais e culturais, vêm obtendo bons resultados terapêuticos ao acompanhamento e tratamento com medicamentos 
antirretrovirais (TARV). Esses pacientes eram acompanhados no Ambulatório de Medicina Integral do Hospital Universitário Pedro Ernesto (HUPE/UERJ) por residentes, médicos e preceptores do Departamento de Medicina Integral, de Família e Comunidade há pelo menos cinco anos.

A seleção dos pacientes foi realizada pelos médicos assistentes desse ambulatório, após conversa com os pesquisadores, quando estes explicitavam os objetivos da pesquisa. Assim, os médicos assistentes selecionavam os pacientes, explicavam a proposta da pesquisa e, após o consentimento destes, eram apresentados ao pesquisador para ser marcada uma entrevista posteriormente.

As entrevistas aconteceram no próprio ambulatório. Foram aplicadas com a preocupação de escutar e observar a estória de vida, adoecimento e terapêutica de modo que além dos fatos relatados fosse possível identificar a forma como a estória era narrada. As estórias eram contadas com muita vivacidade e emoção, posto que o entrevistador se colocava no papel de ouvinte atento e interessado. Os diálogos envolveram as relaçôes entre o adoecimento e o contexto socioeconômico e cultural; entre as repercussões físicas, morais e sociais da infecção e do tratamento e as estratégias de enfrentamento, negociação e manejo terapêutico adotadas.

As entrevistas gravadas foram transcritas e cada fala foi analisada e interpretada como um texto que expõe uma identidade a partir de uma ideologia e, assim, integra dialeticamente a construção de significados e o modo de organizar objetos e percepções, isto é, a trajetória e os sentidos atribuídos pelas pessoas às suas vivências (BROCKMEIER e HARRÉ, 2003; BAKHTIN, 2004). Desenvolveu-se, dessa maneira, um processo interpretativo que procurou entender o sentido que cada pessoa construiu sobre a vida com HIV, sobre o adoecimento e a terapêutica.

\section{Resultados e discussão}

\section{Apresentação dos sujeitos}

A partir da análise das entrevistas foi realizada uma descrição sintética de cada indivíduo, que compreende os aspectos objetivos de suas vidas e os sentidos percebidos de cada narrativa em relação ao binômio vida-adoecimento.

Carolina, 34 anos, natural do RJ, casada e mãe de dois filhos, diagnóstico de SIDA há nove anos. No momento da entrevista seu marido estava cumprindo pena legal em prisão fechada, e, por isso, mora com irmão e filhos. Refere ter completado o ensino médio e está desempregada. Relata ser heterossexual e evangélica praticante. A estória de adoecimento de Carolina é envolvida por uma culpa em relação ao contágio pelo 
HIV. Essa culpa se estrutura com referência a questão religiosa que ajuda a formar como componente central a ideia de ser vítima dos aspectos sociais e da infecção.

Porque é assim lá na igreja, se você tem alguma doença é porque você caiu no pecado, como se você fosse culpado pela sua doença, ainda mais esta né! Mas o problema foi lá atrás, antes de en encontrar Jesus.

André, 52 anos, natural do RJ, casado, mora com esposa e filhos, diagnóstico de SIDA há 9 anos. Formação técnica e desempregado. Relata não ter religião e ser heterossexual. Sua narrativa sobre o adoecimento se forma a partir da ideia de que o contágio foi decorrente de um comportamento promíscuo que ele atribui às suas carências afetivas familiares. Contudo, essa mesma condição de carência se transforma num discurso de enfrentamento, de sobrevivência às adversidades da vida, que ele utiliza como enredo em sua narrativa sobre a doença.

Com o advento do HIV, já viu né, eu fui uma vítima, eu não, todo mundo, a maioria das pessoas que são vitimas do HIV têm problemas com o sexo, é claro, é a principal forma de contaminação.

Assim, minha vida antes do HIV sempre foi uma vida de superar barreiras, entendeu, com rejeição danada de pai e mãe, entendeu, isso tudo me fez uma pessoa lutadora para enfrentar.

Rosane, 35 anos, natural do RJ, viúva, mora com filha. Ensino médio incompleto e sustenta-se com a pensão do marido que é falecido. Declara-se heterossexual. Tem diagnóstico de SIDA há 9 anos. Sua fala se caracteriza pela positividade em relação à vida e uma visão do tratamento que reforça essa idéia. Mesmo diante das repercussões físicas e sociais (sequelas motoras da doença, perda do marido, desemprego, falta de apoio familiar) causadas pelo adoecimento, sua narrativa é emoldurada com um otimismo que parece contribuir para uma atitude positiva de movimento para vida.

Minha vida é estável, com o HIV do meu lado, fica igual uma sombra, teimoso né! Adoro viver, adoro viver...

Fernando, 46 anos, natural do Maranhão, solteiro, mora com irmão, cunhadas e sobrinhos, SIDA há 13 anos. Sua religião é a Espírita, tem o ensino fundamental incompleto e trabalha como ambulante. Declara-se homossexual e sua narrativa é pautada na dificuldade de aceitação de sua sexualidade. O preconceito em relação ao gênero permeia e desestabiliza suas relações sociais, familiares e de trabalho. Nesse contexto sua narrativa caracteriza-se pela busca de uma identidade e de uma imagem pessoal mais aceita e legitimada socialmente.

Eu fiz muitas amizades no Méier que são todas pessoas de bem, pessoas de nivel [...]. Eu sempre procurei andar com pessoas assim. Sou uma pessoa honesta, não tenho rabo preso com ninguém, sou uma pessoa integra, todo mundo gosta de mim lá no bairro, porque lá eu vivo normal, como uma pessoa normal.

Edivaldo, 39 anos, natural do RJ, mora com companheiro, SIDA há 5 anos, possui o ensino médio completo e está em benefício por doença. Refere ser homossexual. A religião tem um importante papel social por exercer a função de "pai de santo" que foi prejudicada com a doença. Sua vivência sexual é descrita com naturalidade o que contrasta 
com o preconceito em relação à doença. Vivencia esse preconceito no olhar dos outros, como uma imagem que se torna a justificativa para seu isolamento social e profissional. Não, [sobre conseguir voltar à sua vida normal] não consegui ainda, mas assim tudo você tem que inventar desculpas já que você não quer contar nada para ninguém. Eu não quero me expor, porque sei que as pessoas ainda são podres...

Renato, 45 anos, natural da Bahia, solteiro, mora sozinho, religião espírita e SIDA há 7 anos. Tem formação técnica e está em beneficio por doença. Refere ser heterossexual. Essa narrativa se diferencia pelo sentimento de alívio e redenção do paciente com diagnóstico da Aids, pois, indiretamente o tratamento pelo HIV resolveu uma dor no joelho que limitava sua vida. A narrativa do adoecimento se sobrepôs à narrativa pessoal e aos aspectos morais, à medida que o paciente vê o diagnóstico e o tratamento do HIV como forma de aliviar seu sofrimento e continuar sua vida.

Quando o resultado veio positivo, no momento para mim foi um alivio, porque ai eu sabia o que eu tinha... Eu tava tão ruim do reumatismo, que o HIV veio como uma solução para mim.

João, 55 anos, natural do RJ, solteiro, mora sozinho, SIDA há 15 anos. É aposentado pela doença e tem formação técnica. Não declara nenhuma religião. Narra uma longa história de adoecimento em que prioriza sua experiência de dependência química. A dificuldade em superar a drogadicção cria uma narrativa na qual os aspectos morais envolvidos com o contágio pelo HIV e o enfrentamento da doença são secundários. Há uma história de superação do sofrimento causado pela dependência química e uma compreensão de que a saúde está integrada às suas escolhas e atitudes emocionais perante a vida.

É que toda vez que meu emocional cai de alguma maneira, mexe na minha imunidade. Porque assim, eu sou muito positivo, não penso na doença, vivo normalmente, gosto de mim, gosto de viver, e vou vivendo.

Gisela, 45 anos, natural do RJ, casada, mora com esposo e filhos, SIDA há 11 anos. Cristã, mas sem nenhuma religião especifica. Tem o ensino fundamental completo e trabalha como ambulante. Sua narrativa é demarcada pelo enfrentamento das dificuldades na vida (social, familiar e econômica), através de um comportamento defensivo em que o HIV assume o papel de mais uma dificuldade a enfrentar. Apesar do movimento atual de aceitação da doença, ainda prefere se esconder atrás de um pressuposto diagnóstico de câncer, para não ter que admitir para a sociedade e para si mesma, sua exposição ao HIV.

Minha vida é essa luta toda, mas em relação à doença eu nem penso nisso, eu não fico pensando que eu estou doente. Agora, eu também não falo para todo mundo que eu estou com isso [...]. Tem outros que me perguntam do que eu estou doente e eu falo que estou com um caroço [...] que Deus me perdoe, mas fica sendo como se eu tivesse um câncer, mas não falo que é o HIV.

Eduardo, 60 anos, natural do RJ, separado, mora sozinho e é aposentado por tempo de serviço. Refere ser católico e ter ensino médio incompleto. Tem SIDA há 5 anos. 
Em seu relato, vê o contágio como uma resultante de sua fuga da solidão, após o di-

vórcio e o afastamento da família, porém o próprio diagnóstico ocasionou a retomada dos laços familiares. Em sua vivência, ver os resultados práticos do tratamento foi muito importante para aceitação do adoecimento. Passou a crer que não iria morrer num futuro próximo e que ainda fazia sentido fazer planos para a vida.

Sinto sim, assim, eu entrei nessa por desespero, mais que desespero era uma fuga... de repente, depois de 30 anos casado, eu separo. Viver sozinho dentro de uma casa era uma tristeza, era olhar para um e olhar para o outro, não tinha ninguém, ai foi isso que me levou para o mundo. Ai foi que eu caí, mas agora já me levantei de novo.

\section{Avaliação comparativa das trajetórias de adesão ao tratamento anti-retroviral (TARV)}

Ressalta-se das falas a diversidade de contextos pessoais e culturais que dão singularidade a cada trajetória narrativa. Porém, a observação dessas estórias em relação à infecção e ao tratamento evidencia, como uma característica comum, a forma não linear e descontínua das pessoas lidarem com a adesão aos tratamentos propostos.

Observa-se que as narrativas dos pacientes não abordaram as interrupções ao tratamento como uma descontinuidade terapêutica. Em suas perspectivas, esses períodos estavam inseridos em uma mesma noção de tempo a qual não diferenciava os momentos de adesão ou não. As narrativas, portanto, expunham uma dimensão temporal que não situava a adesão de forma cronológica. Ao contrário, as idéias de continuidade ou descontinuidade tinham sentidos que integravam e hierarquizavam diversos valores e situações em diversas nuances. Desse modo, em todas as falas, as noçôes de tempo, em relação tanto aos momentos de afastamento como os de adesão, sempre envolveram circunstâncias da vida e do adoecimento que impactaram ou impulsionaram o progresso da vida e, consequentemente, as estratégias terapêuticas.

\section{Avaliação comparativa do significado do preconceito em relação ao HIV}

Nas falas dos entrevistados pôde-se observar que as percepções e representações quanto à infecção pelo HIV eram semelhantes ao relatado em outros trabalhos que abordam a construção de sentidos em relação ao adoecimento por HIV/ Aids (SILVA, 2008). Tais falas sobre a doença envolvem, frequentemente, uma preocupação em criar justificativas morais para a infecção e para o adoecimento. 
Há, assim, um predomínio de sentimentos como os de culpa e de rejeição relacionadas aos preconceitos sociais e culturais que, por sua vez, tornamse elementos das narrativas que dirigem a construção de significados sobre o adoecimento para aquém e além do contágio pelo vírus. Nas entrevistas pôde-se observar como as vivências com o preconceito relacionado ao gênero e/ou aos comportamentos socialmente discriminados eram centrais na construção das narrativas sobre o adoecimento.

Minha vida antes era casado, fui casado por 25 anos, tenho filhos e netos, ai depois deste
perído todo eu me separei, \{\} fiquei sozinho, aí veio aquela depressão. \{\} Foi quando eu
conheci pessoas, né, e acabei pegando esta doença (Eduardo).
Desde pequeno descobri o sexo, tipo uma muleta, \{\} aquilo me dava prazer, tipo uma ca-
chaça. Para sobreviver eu fui levando o sexo como uma muleta... Com o advento do HIV,
já viu né, eu fui uma vítima... (André).

O olhar mais atento sobre os relatos dos pacientes evidencia, contudo, que as pessoas lidam de maneira diferente com os preconceitos e valores morais que os cercam. Essa singularidade pôde ser reconhecida observando-se a forma, o significado e a intencionalidade de como os estigmas e as rupturas morais são incorporadas em suas narrativas sobre a vida e o adoecimento.

Para entender e categorizar as construções de sentidos pessoais que conduziram o enfrentamento das limitaçôes e impulsionaram a adesão terapêutica, foi realizada uma abordagem interpretativa em busca de padrões e direçôes dentro da singularidade das narrativas.

\section{A identificação do protagonismo como norteador do projeto terapêutico pessoal}

A singularidade inerente à abordagem das narrativas representa uma vantagem e um desafio para investigar como se organizaram as falas e atitudes que influenciaram a adesão terapêutica. Para superar esse desafio foi preciso ir além da identificação de quais eram os elementos morais, sociais ou afetivos presentes nas narrativas. Foi necessário identificar os sentidos e os valores que norteavam as estórias e que eram responsáveis por impulsionar a construção dos arranjos integradores das dimensões pessoais e aquelas relativas ao processo de adoecimento.

A partir dessa perspectiva analítica, foi possível perceber uma linha de significados, que parece ser relevante para compreender esse movimento em direção à adesão. Foi possível reconhecer que nas narrativas havia um forte 
protagonismo, isto é, falas e atitudes em que os pacientes se reconhecem como sujeitos na organização das estratégias para enfrentar as limitações morais e sociais decorrentes do preconceito ou do estigma com a doença.

Essa perspectiva de protagonismo se remete à ação, à interlocução e à atitude dos sujeitos, isto é, quando e como eles buscam ocupar lugar central nos acontecimentos. Esse protagonismo se insere, portanto, no movimento de construção do papel de sujeito autônomo e corresponsável no processo de produção de sua própria saúde (BRASIL, 2008).

É um protagonismo que se formou nos discursos por conta da tendência dos sujeitos em criar novos arranjos integradores de questôes físicas, morais e sociais que envolviam o mundo do adoecimento pelo HIV/Aids. Identificou-se que era a partir desse protagonismo, e entorno dele, que as pessoas organizavam suas estratégias de explicação, enfrentamento e superação dos conflitos morais e sociais utilizando-se de diferentes recursos narrativos e semióticos.

Para melhor entender esse protagonismo analisou-se, mais especificamente, a forma como os pacientes lidam com três questôes recorrentes em suas estórias: o enfrentamento das rupturas morais (decorrentes de seu convívio e meio social como preconceitos e estigmas em relação ao gênero e à infecção pelo HIV) sociais (dificuldades de inserção no trabalho e as dificuldades econômicas nas famílias e pessoais advindas do adoecimento); assim como mudanças nas percepções do adoecimento e a vivência do processo terapêutico.

\section{Enfrentamento das rupturas morais e sociais}

Uma das formas encontradas pelos pacientes para enfrentar a discriminação e o preconceito, por mais contraditória que pareça, organizou-se em torno da ideia da autovitimização. Partindo da ideia de ser vítima de uma fraqueza, a pessoa parecia desenvolver estratégias de revalorização e reconstrução de sua autoestima e de suas relações sociais. Forma-se um recurso narrativo que reduz a importância da discriminação em relação ao seu comportamento, o qual atribui ao destino e/ ou à sua formação familiar. Dessa maneira, os sujeitos parecem ter conseguido sobrepor os julgamentos externos e continuar a conduzirem sua vida.

Minha vida sempre foi de superar barreiras, eu fiquei um solitário sobrevivente, e sempre elegi o sexo como uma cachaça, uma muleta. Ainda bem que eu não descambei para o crime ou para drogas (André). 
O mesmo recurso é encontrado para lidar com o preconceito relativo à homossexualidade, através de uma narrativa que busca um modo de ser no mundo que independa das questôes de gênero. Nesse sentido, os sujeitos procuram formas de legitimação social (como a valorização do seu trabalho/autonomia econômica) e afetiva (organizando novas trocas afetivas) que independem da questão de gênero.

[...] eu tinha que assumir, que se Deus tinha me feito assim que eu tinha que aceitar, porque a gente não pede para nascer assim, que era um destino, porque se gente já nasce assim, então era uma coisa de Deus, você não pode, tem que ser o que é, tem que lutar para ter sua vida, viver tua vida... (Fernando).

Outro recurso narrativo e prático foi o de não admitir ou incorporar a discriminação para si. Uma narrativa que reconhece que o preconceito está localizado nos outros e não em si mesmo. Formam-se estratégias para evitar a exposição às situações ou às pessoas que podem discriminá-lo e fragilizá-lo, fazendo um manejo de sua fala e de suas atitudes de modo a se desviar desses contextos de discriminação. Portanto, tal conduta não se coloca como uma fuga, mas como uma estratégia de enfrentamento e superação.

Eu me afastei porque eu sentia eles me tratando diferente dentro de casa... minha mãe não me deixava a vontade na casa dela, fiquei chateada, muito chateada, eu tinha que avisar quando ia no banheiro, ela separava o copo, me deu o lençol que eu usei. Eu sei que não se pega assim, mas ela é cabeça dura (Rosane).

Observa-se, portanto, a existência de um movimento de enfrentamento das rupturas morais e sociais através de narrativas que tornam secundárias as questôes referentes aos preconceitos, julgamentos e discriminações a que os pacientes estão expostos. Assim, busca-se a revalorização da auto-estima através da legitimação pessoal e social, dirigida pelo papel de protagonista que as pessoas assumem, ao reescreverem suas estórias sob um contexto de relações e percepçóes de enfrentamento do adoecimento.

\section{As mudanças nas percepções do adoecimento}

Em quase todos os relatos, a descrição do impacto do diagnóstico da infecção está envolvida pelo medo, advindo de uma percepção fatalista que inclui as ideias de degradação, sofrimento e morte iminente, que são muitas vezes reforçadas por debilidades físicas presentes na época do diagnóstico. Esse medo se exterioriza nas expressões e atitudes desesperadas, assim como nas dúvidas quanto ao futuro. Em alguns casos, além da referência ao sofrimento pessoal, 
surge a preocupação com filhos e a família em geral. Esse sentimento abrange

questões como a vergonha em relação à infecção e até a apreensão em como manter o provimento para seus familiares.

Só pensava que ia morrer. Peguei e vou morrer. Não pensava que com o tratamento daria para viver muito tempo (Eduardo).

Eu tirei a conclusão como se fosse igual o Cazuza né, é o fim, o fim de dois caixões, meu e dele [do companheiro] (Gisela).

Ter que conviver com isso é muito difícil, é dormir e não saber se vai acordar (Eduardo).

Eu não tinha perspectiva de vida, porque meus amigos todos estavam morrendo, morreram praticamente todos da minha época, poucos se salvaram, era para morrer, tava só esperando chegar minha hora (João).

Em dois entrevistados, entretanto, esses sentimentos de medo e desespero com o diagnóstico não apareceu nas suas falas. Foram situações especiais, mas que explicam como sentimentos e valores podem mudar em decorrência do contexto biopsicossocial em que as pessoas se inserem.

Em um desses casos, o diagnóstico do HIV se deu em meio a um longo e grande esforço para enfrentar a drogadicção e todas as suas repercussões físicas e socioeconômicas. Sentindo-se fortalecido por sua vitória contra a droga e pelos valores que desenvolveu em relação à saúde e à vida, o vírus é visto como mais uma etapa de luta pela vida. Na estória de outro sujeito, o diagnóstico e o tratamento para o HIV representaram a possibilidade de explicar e eliminar o sofrimento causado por intensas e incapacitantes dores articulares.

[...] eu precisava de uma resposta do que que eu tinha, porque esse tratamento com aqueles remédios (para reumatismo) não estavam adiantando nada, dai pedi ao médico um teste anti-HIV para mim, porque eu preciso de uma resposta, do que eu tenho. Quando veio o resultado positivo para mim foi um alivio, porque ai eu sabia o que eu tinha (Renato).

As estórias contadas pelos entrevistados demonstraram que os sentimentos e significados presentes no momento do impacto do diagnóstico vão se modificando com o tempo de convívio com a doença. As pessoas começam a perceber que apesar da infecção não vão morrer e, mais ainda, que precisam viver e conduzir as questôes de seu cotidiano.

Eu venho vendo que está melhorando, porque eu me preocupava muito quando eu ficava resfriado [...] Mas ai Graças a Deus, o resultado saindo bem eu não tenho mais muito preocupação, parei de pensar nisso. A minha preocupação é da fraqueza, e o medo, porque dá medo de morrer e ninguém quer morrer e não ter os desejos realizados. [...] A gente quer sempre viver, mas agora vivo uma vida normal, Graças a Deus (Eduardo). 
Algumas falas apontam para a construção de novos sentidos para a vida, de revalorização de aspectos da saúde e do autocuidado que antes não eram valorizadas. Essas narrativas estão envolvidas por um sentimento de vitória contra as adversidades da vida, e a infecção representa apenas mais uma delas. Outros simplesmente demonstram desvalorizar a importância do vírus e enfatizam suas conquistas na reorganização das relações afetivas, no trabalho, na participação em grupos religiosos e, assim, percebem que estão reduzindo o impacto inicial e reconstruindo novos modos de andar suas vidas.

HIV não é uma sentença. A gente cresce muita com nossas lutas e dificuldades... Hoje eu tenho mais cautela nas coisas que eu vou fazer, não sou mais inconseqüente, o HIV para mim veio como uma lição, naquela época foi como uma pedra, mas hoje é uma palavra, uma lição, que a gente não tem que se condenar pelo o que já fez, e sim que temos que nos amar, nos cuidar mais, afinal não é caindo que se aprende, igual andar de bicicleta, né? É nos erros que aprendemos a acertar (Carolina).

Esses processos que os pacientes produzem de ressignificação da doença em suas vidas e/ou da vida a despeito da doença são explicados pelas pessoas de modo muito singular. Algumas pessoas atribuem as suas estórias de vida a modos de agir anteriores à infecção.

Eu sempre fui uma pessoa legal (Fernando).

Eu aprendi a superar barreiras desde pequeno (André).

Eu gosto muito de mim mesmo, gosto de viver, gosto da vida, entendeu, e se eu estou bem, vou lutar para continuar bem. Eu sempre fui muito positivo neste ponto (João).

Outros atribuem tais histórias ao apoio afetivo ou social de algumas pessoas especiais, como companheiro, irmão, etc. Também há relatos que justificam sua atual condição de enfrentamento com a participação em grupos de apoio ou religiosos nos quais essas pessoas se inseriram e identificaram uma nova identidade social.

O grupo no início te auxilia muito. No sentido sobre a doença, sobre as doenças paralelas, só que com o tempo você passa a saber tudo [...] Mas tem os novos que estão entrando, que precisam de apoio, que estão desesperados, que querem se matar, então você que já está neste barco há 9 anos você já sabe de tudo (André).

É, é um lugar onde eu tenho muita força. Acho que a vida espiritual da gente, faz parte igual uma comida, tem que ter uma parte espiritual, uma igreja, qualquer lugar. O centro espírita assim me dá a maior força, eu sinto uma energia positiva boa (Renato). 
Apesar da atenção profissional não ter aparecido como um elemento central na justificativa do enfrentamento da doença, ela surgiu como um aspecto positivo em todas as falas. Todas sinalizaram a importância do acolhimento recebido, das explicações e da cumplicidade que desenvolveram com as equipes.

Não (não parei de tomar a medicação), é porque depois que eu comecei a tratar com a Dra Joana (nome fictício), porque ela me ajudou muito sabe, ela me ajudou muito mesmo, eu chegava chorando muito, eu falava com ela cheio de problema, ai ela me deu a maior força mesmo, ela teve paciência comigo (Fernando).

Desde que eu sei que sou soropositivo só falta os médico me carregarem no colo, me deu prioridade, me passou na frente. Quando eu cheguei aqui no Rio, eu vim procurar este hospital [...] foi o Dr. Mário (nome fictício) que me atendeu, quando eu mostrei para ele meu diagnóstico ele me atendeu que só faltou me carregar no colo (Renato).

Parece que o fio que tece a adesão e o sucesso prático terapêutico, em meio a essa heterogeneidade de caminhos percorridos e de justificativas apresentadas pelos pacientes para o enfrentamento do adoecimento, está, mais uma vez, no protagonismo que essas pessoas assumiram em seu processo saúde-adoecimento-terapêutica.

\section{Vivências do processo terapêutico}

Esse protagonismo fica mais claro nas referências ao manejo do tratamento e da procura por atenção. Essa ação pôde ser percebida em todas as falas desses pacientes, que possuem o perfil de boa adesão e boa evolução clínico-laboratorial. Suas narrativas demonstraram uma relação de cumplicidade com a terapêutica, tanto no ponto de vista da medicação como do relacionamento com a equipe.

Tinha sim, tinha uma boa relação com ela, (a médica) e com a psicóloga daqui. Elas pegavam muito no meu pé por causa desse negócio de não tomar os remédios direito sabe. Eu via nelas o apoio que na igreja eu não tinha, na igreja era sim "Deus vai curar, que não precisava tomar remédio", mas eles falavam uma coisa e faziam outra, então quem eu ia ouvir? (Carolina).

Outro aspecto que constrói essa ideia de que esses pacientes se colocaram como protagonistas de suas estórias foi a prevalência em suas falas da referência ao autocuidado. Reiteravam a importância de se cuidarem, de terem uma vida mais saudável, para alcançarem maior sucesso terapêutico. Essa percepção de cuidado é, por vezes, exposta como certo virtuosismo, como uma condição de sabedoria e de força no enfrentamento da doença. Esse virtuosismo também 
pode ser visto como uma resposta ao preconceito, ao comportamento julgado como irresponsável pelo grupo social.

A dedicação de tomar os remédios, o descanso à noite, a alimentação boa, tomei muita vitamina, procuro não me perturbar com muita coisa, e acho que é isso que me deixa tão bem (Edivaldo).

É importante a cabeça, tomar o remédio certinho como eu tomo, outra coisa seu modo de vida, comer direito, um leguminho, uma fruta (André).

Outra perspectiva identificada com frequência é a importância da visualização do sucesso do tratamento como um feedback positivo para a adesão, pois ao observar a boa evolução, o paciente acredita que é possível ter uma vida normal e investe nesse sentido. Esse feedback se organiza, também, em torno de uma nova noção do tempo futuro: o que era uma possibilidade inexistente passa a ser um elemento modificador do presente.

Tenho consciência que tenho que tomar meus remédios, são meus aliados, não posso ficar sem os remédios. Tenho consciência. Meu remédio são minhas roupas, você não pode ficar sem roupa, né? (Rosane).

Os frutos que a gente colhe hoje são as sementes que a gente plantou ontem, por isso eu comecei a aderir o tratamento, porque hoje eu vi que tem resultados, eu estou bem (Carolina).

O bichinho não é tão bravo como parece, desde de que você tenha disposição de enfrentar. É só um RNA que tem que se transformar em DNA, quantas moléculas de DNA eu tenho no corpo?. Depende muito da pessoa e do avanço da ciência (André).

Assim, observa-se que as vivências do processo terapêutico formam um leque de possibilidades. Neste, a iniciativa, o protagonismo e o entendimento de que o tratamento é parte de um processo amplo para além da tomada diária dos medicamentos fazem parte das vivências desse grupo de pacientes. É interessante observar a importância de tais pontos, pois, se a equipe identificar narrativas que caminham para esse sentido, pode produzir um reforço positivo, adequado para que tais vivências perpetuem-se no sentido do sucesso prático almejado, isto é: autonomia, autocuidado e qualidade de vida.

\section{Considerações finais}

As estórias, apesar das singularidades de seus enredos, se assemelham em relação ao movimento de protagonismo que os pacientes fazem para enfrentar as dificuldades e barreiras impostas no curso da vida e do adoecimento. Tal 
protagonismo se destaca nas narrativas desse grupo de pacientes que, expostos a

diversas vulnerabilidades e às conseqüências físicas e morais do adoecimento pelo HIV, conseguem caminhar na direção de um sucesso prático, tanto em relação à adesão terapêutica como no modo de manejar a vida.

Esse protagonismo foi percebido na forma como as pessoas se referiram aos seus hábitos de vida, dando ênfase ao autocuidado, expressando mudanças em sua visão sobre saúde e sobre o manejo do tratamento. Por outro lado, agenciaram mudanças narrativas que possibilitaram avançar sobre o imobilismo produzido pelas questôes morais causadas pelo preconceito de gênero ou da SIDA. Esse conjunto de ações, portanto, parece ter um papel significativo na construção de novos sentidos para as próprias barreiras e sofrimentos, assim como a estratégia que as pessoas desenvolvem para enfrentá-los.

A análise das falas mostra como as narrativas dos pacientes se constroem através de trajetórias não lineares e descontínuas. Essa imagem de aparente irregularidade temporal e espacial se forma na relação das pessoas com os objetos e significados que elas incorporam sobre o adoecimento, e também na relação deste com o processo terapêutico, mais especificamente com a adesão.

A relação que as pessoas demonstram com a adesão é dinâmica, tanto na dimensão temporal quanto circunstancial, na medida em que seus sentidos mudam no decorrer do tempo, assim como é uma relação costurada por fatores externos e internos presentes em cada momento vivenciado pelo paciente.

Para os profissionais de saúde, captar a variabilidade e a singularidade de tais dimensões da adesão contribui para a estruturação do vínculo terapêutico em qualquer momento desse processo descontínuo. Como foi discutido, a experiência terapêutica teve ligação com a relação entre os pacientes e a equipe. Nesse processo relacional e dialógico percebe-se, portanto, a importância de os profissionais de saúde compreenderem que o paciente não é aderente, e sim que ele está aderente, e que a adesão faz parte de um modo de ser e estar, fundado no cotidiano do paciente, sujeito às variabilidades e diretamente proporcional ao movimento de autonomia e protagonismo do sujeito.

Conclui-se ser importante para o sucesso terapêutico pretendido pela equipe de saúde a compreensão de como os pacientes elaboram sua relação com o adoecimento e os manejos estratégicos que estes organizam para lidarem com as dificuldades e rupturas criadas pelo adoecimento. 
Por fim, este estudo aponta para a importância da qualidade da escuta e da atitude necessária ao acolhimento realizado por parte dos profissionais para ampliar a adesão, a autonomia e a qualidade de vida de pessoas portadoras de Aids. Para ilustrar tal importância, transcrevemos a frase final da entrevista com Rosane, na qual se evidencia como nesse universo do HIV/Aids, o acolhimento humanizado, em qualquer direção, faz toda diferença:

Eu não sei quem passou para um ou outro, eu não sei, a gente nunca discutiu sobre isso, nunca acusou um ou outro, a gente se apoiou um ao outro. Ele era meu amigo, amigo se acolhe.

\section{Referências}

BAKHTIN, M. Marxismo e filosofia da linguagem. 11 ed. São Paulo: Hucitec, 2004, 193p. BONET, O.; TAVARES, F.R.G. O usuário como mediador. Em busca de uma perspectiva "ecológica" sobre os condicionantes sociais da saúde. In: PINHEIRO, R.; MATTOS, R.A. (Org.). Cuidar do Cuidado: responsabilidade com a integralidade das açóes de saúde. Rio de Janeiro: Cepesc, 2008, p 191-212.

BRASIL. MINISTÉRIO DA SAÚDE. Adesão aos anti-retrovirais - Manual para os profissionais de saúde, MS/Brasil, Programa Nacional de DST/Aids, Brasilia - DF, 2005, 86p. Secretaria de Atenção à Saúde. Núcleo Técnico da Política Nacional de Humanização. HumanizaSUS. Documento base para gestores e trabalhadores do SUS. 4. ed. Brasília : Ministério da Saúde, 72 p. 2008.

. Resolução CNS no196/96. Dispõe sobre pesquisa envolvendo seres humanos. Conselho Nacional de Saúde. Brasília: Ministério da Saúde, 1996.

BRITO, A.M. A evolução e distribuição social da doença no Brasil. Disponível em: < http:// www.comciencia.br/comciencia/handler.php? section $=8 \&$ edicao $=13 \& \mathrm{id}=116>$. Acesso em: 20 out 2008 .

BROCKMEIER, J.; HARRÉ, R. Narrativa: problemas e promessas de um paradigma alternativo. Psicologia: Reflexão e Crítica, Porto Alegre, v. 16, n. 3, p. 525-535, 2003.

BRAWLEY, L.R.; CULOS-REED, S.N. Studying Adherence to Therapeutic Regimens: Overview, Theories, Recommendations. Controlled Clinical Trials, Nova York, v. 2, p. 156S-163S, 2000.

BURY, M. Illness narrative: fact or fiction? Sociology of Health \& Illness. Londres. v. 23, n. 3, p. 263-285, 2001.

CAMARGO JR, K.R. Biomedicina, Saber \& Crítica. São Paulo: Hucitec, 2003, p. 195. 
CANGUILHEM, G. Normal e o patológico. 2a ed. Rio de Janeiro: Forense Universitária; 1982. 270p.

CHARON, R. Narrative and Medicine [Perspective]. New England Journal of Medicine. Massachusetts, v. 350, n. 9, p. 862-864, 2004.

DONALD, A. The words we live in. In: GREENHALGH, T.; HURWITZ, B. Narrative Based Medicine. $3^{\mathrm{a}}$ ed. Londres: BMJ Books, 2002, p. 17-28.

FAVORETO, C.A.O. A Narrativa na e sobre a Clínica na Atenção Primária: uma reflexão sobre o modo pensar e agir dirigido pelo diálogo à integralidade e ao cuidado em saúde. 2007. 216 p. Tese (Doutorado em Saúde Coletiva) - Instituto de Medicina Social, Universidade do Estado do Rio de Janeiro, Rio de Janeiro, 2007.

. A construção e avaliação da clínica na perspectiva da integralidade: uma rede complexa de palavras e coisas e de saberes e práticas. In PINHEIRO, R.; MATTOS, R.A. (Org.) Gestão em Redes: práticas de avaliação, formação e participação na saúde. Rio de Janeiro: Cepesc, 2006, p. 185-204.

FRANK, A.W. The Wounded Storyteller. London: The University of Chicago Press, 1995. 213 p.

HYDÉN, L.C. Illness and Narrative. Sociology of Health \& Ilness. Londres. v. 19, n. 1: p. 48-69, 1997.

LEITE, S.N. Adesão à terapêutica medicamentosa: elementos para a discussão de conceitos e pressupostos adotados na literatura. Ciênc. saúde coletiva. São Paulo, v. 8, n. 3, p. 775-782, 2003. MATTOS, R.A. Integralidade, trabalho, saúde e formação profissional: algumas reflexões críticas feitas com base na defesa de alguns valores. In: MATTA, G.C.; LIMA, J.C.F. (Org.). Estado, Sociedade e Formação Profissional em Saúde: contradições e desafios em 20 anos de SUS. Rio de Janeiro: Fiocruz, 2008. p. 313-354.

PINHEIRO, R.; MATTOS, R.A. (Org.). Razôes públicas para a integralidade em saúde: o cuidado como valor. Rio de Janeiro: Cepesc, 2007, p. 279-300.

SCHAURICK, D.; COELHO, D.F.; MOTTA, M. da G.C. . A cronicidade no processo saúde-doença: repessando a epidemia da Aids após os anti-retrovirais. Rev. Enfermagem da UERJ, Rio de Janeiro, v. 14, n. 3, p. 455-462, 2006.

SILVA, G.A.; TAKAHASHI, R.F. A busca pela assistência a saúde: reduzindo a vulnerabilidade ao adoecimento entre os portadores do HIV. Revista de Atenção Primária à Saúde, Juiz de Fora, v. 11, n. 1, p 29-41, 2008.

REINERS, A.A.O. et al. Produção bibliográfica sobre adesão/não adesão de pessoas ao tratamento de saúde. Ciência e Saúde Coletiva, Rio de Janeiro, v. 13, sup. 2, p. 2229-2306, 2008. 
Analysis of the narrative of HIV patients: the
building of therapeutical adhesion

Adhesion to antiretroviral treatment for Aids patients must be approached from a multi-factor and particular viewpoint, considering sociocultural aspects, built meanings and subjects' autonomy. This qualitative study aims to explore elements and narrative forms developed by patients so as to promote adhesion. In-depth interviews with nine Aids patients who had good adhesion, as well as clinical and laboratorial response to treatment, were conducted. The analysis of speeches identified the contexts and narrative discourses that helped these people face the illness and its repercussions, and that influenced on adhesion. It was noticed that the timing of adhesion in narratives was not chronological and the justification/explanation for dealing with infection, disease and prejudice acquired therapeutical dimension. The protagonist's role in life and illness histories became a central element while facing disruptions arisen from illness and influenced on adhesion incorporation in a therapeutical perspective.

> Key words: Acquired Immunodeficiency Syndrome; patient compliance; narrative medicine; chronic disease. 